\title{
Książki wydane przez pracowników i doktorantów zakładów językoznawczych Instytutu Filologii Polskiej UAM w Poznaniu w roku 2011
}

Stanisław B ąb a, Jarosław Lib e rek, Ze studiów nad frazeologiq wspótczesnego jezzyka polskiego, Wydawnictwo Poznańskie, Poznań 2011, ss. 132.

$\mathrm{Na}$ tom składają się materiałowe i teoretyczne szkice i artykuly z lat 1987-2010 napisane wspólnie przez obu autorów. Tematycznie skupiają się one wokół takich zagadnień, jak: sposoby pomnażania zasobu frazeologicznego polszczyzny po roku 1968, leksykograficzne ujęcie współczesnej frazeologii, zmiany znaczeń polskich frazeologizmów, leksykograficzne ujęcie fraz jako jednostek frazeologicznych, interpretacja współczesnego uzusu frazeologicznego, derywacja frazeologiczna oraz opis nowych i tradycyjnych polskich zwrotów typu kręcić lody, mieć kogoś na widelcu, stroić się $w$ cudze piórka, a także takich regionalizmów frazeologicznych, jak mieć dlugie zęby na co, nie urywać sobie rękawów. Wszystkie wiążą się z praktyką frazeograficzną obu autorów, powstały bowiem niejako na marginesie prac nad przygotowywaniem czterech słowników frazeologicznych. Pod względem teoretycznym mieszczą się w nurcie badań frazeologicznych uprawianych przez Stanisława Skorupkę i jego kontynuatorów. Ich mocną stroną jest prezentowany w nich współczesny materiał zaczerpnięty z Korpusu Frazeologicznego Języka Polskiego, gromadzonego od wielu lat w Pracowni Leksykograficznej Instytutu Filologii Polskiej Uniwersytetu im. Adama Mickiewicza w Poznaniu.

Norma jezykowa $w$ aspekcie teoretycznym $i$ pragmatycznym, pod redakcją Anny Piotrowicz, Malgorzaty Wit a sz e k-S a m b o r s ki e j i Krzysztofa Skibskiego, Wydawnictwo Poznańskiego Towarzystwa Przyjaciół Nauk, Poznań 2011, ss. 265.

Zamieszczone w książce artykuły układają się w dwa bloki tematyczne. Teksty dotyczące teoretycznych aspektów normy poświęcone są kryteriom i metodom oceny różnych elementów językowych, kodyfikacji w zakresie łączliwości leksykalnej, skutkom akceptacji wewnętrznego zróżnicowania normy, możliwościom prognozowania ewolucji języka na podstawie normy oraz granicom norm językowej i komunikacyjnej. 
Wśród zagadnień pragmatycznych znalazły się problemy szczegółowe związane ze współczesnym uzusem, z rozmaitymi aspektami normy i błędów w przekazach medialnych oraz $\mathrm{w}$ różnych typach i gatunkach tekstów, z poradnictwem językowym, a także z kryteriami poprawności stosowanymi w odniesieniu do wybranych zjawisk językowych.

Perspektywy wspótczesnej frazeologii polskiej. Wariantywność we frazeologii, pod redakcją Piotra Fli cińskiego, Wydawnictwo Naukowe UAM, Poznań 2011, ss. 103.

Książka jest drugą częścią serii dyskursywnych podręczników z frazeologii i frazeografii obecnej polszczyzny (pierwszy tom - Perspektywy współczesnej frazeologii polskiej. Teoria. Zagadnienia ogólne - ukazał się w 2010 roku również nakładem Wydawnictwa $\mathrm{Na}$ ukowego UAM). Autorzy rozdziałów wywodzą się z różnych ośrodków akademickich w kraju (Kraków, Wrocław, Szczecin, Olsztyn, Warszawa, Poznań). Każdy z badaczy przedstawia szczegółowo zagadnienia związane $\mathrm{z}$ wariantywnością frazeologizmów w polszczyźnie, nie zapominając o dydaktycznym i sprawozdawczym charakterze opisu. I tak Iwona Kosek (UWM) zajęła się problemem wyznaczania granic jednostki leksykalnej w kontekście wielowariantowości idiomów, Alicja Nowakowska (UWr) - wariantywnością porównań frazeologicznych, Jolanta Ignatowicz-Skowrońska (US) - wariancją frazeologizmów na płaszczyźnie ich schematów walencyjnych, Stanisław Koziara (UP) wariantywnością $\mathrm{W}$ opisie frazeologizmów pochodzenia biblijnego. Podręcznik dopełniają stricte frazeograficzne rozdziały przybliżające stan faktyczny realizacji słownikowych poszczegól- nych grup frazeologizmów: Gabriela Dziamska-Lenart zajęła się omówieniem problemu wielokształtności we frazeografii na przykładzie wybranych dzieł leksykograficznych, Magdalena Puda-Blokesz (UP) opisała wariantywność mitologizmów frazeologicznych, a Monika Kącka-Rodak (UW) ukazała sposoby notowania wariantywności związków frazeologicznych w wybranych słownikach ogólnych polszczyzny (frazeologizmy z komponentami serce i głowa).

Agnieszka Piotrowska-Wojaczyk, Regionalizmy leksykalne $w$ stownikach doby nowopolskiej, Wydawnictwo Poznańskiego Towarzystwa Przyjaciół Nauk, Poznań 2011, ss. 549.

Praca wpisuje się w nurt badań nad historycznym zróżnicowaniem regionalnym języka polskiego. Jej zasadniczym celem jest przedstawienie procesu regionalizacji słownictwa $\mathrm{w}$ dobie nowopolskiej (rozumianej za Zenonem Klemensiewiczem jako okres od połowy XVIII do połowy $\mathrm{XX}$ wieku) i wyjaśnienie przyczyn tego zjawiska (omówienie tła historycznego - okoliczności politycznych, społecznych i kulturalnych). Ponadto został w niej ukazany - jako ważny przyczynek do opisu rozwoju warsztatu leksykograficznego w dobie nowopolskiej - stosunek do regionalizmów leksykalnych i sposobów ich leksykograficznego opracowania w słownikach tego okresu dziejów polszczyzny.

Analizie poddano następujące leksykony: Samuel Bogumił Linde, Stownik języka polskiego (t. 1-6, Warszawa 1807-1814), Słownik języka polskiego, wyd. Maurycy Orgelbrand (cz. 1-2, Wilno 1861), Jan Karłowicz, Adam Kryński, Władysław Niedźwiedzki, Słownik języka polskiego (t. 1-8, Warszawa 1900-1927), Stownik języka polskiego, red. 
Witold Doroszewski (t. 1-11, Warszawa 1958-1969) ${ }^{1}$.

$\mathrm{Na}$ podstawie wszelkich informacji geograficznych w nich odnotowanych (zawartych explicite lub implicite w definicjach znaczeniowych, przykładach użycia bądź wynikających z wiedzy o językowej biografii autorów cytowanych przykładów) wyodrębniono zbiór 4940 leksemów. Każdy z nich rozpatrywano we wszystkich czterech słownikach, budując w ten sposób dla poszczególnych haseł pełną metrykę leksykograficzną, rozumianą jako historię ich słownikowych poświadczeń w analizowanych dziełach.

Mimo iż analizowane słowniki zarejestrowały tylko wybór leksyki regionalnej, można przypuszczać, że jest to wybór reprezentatywny, to znaczy - jego podstawowe cechy są tożsame $\mathrm{z}$ wyznacznikami tej odmiany polszczyzny regionalnej, traktowanej jako całość. Przy powyższym założeniu praca stanowi opis polszczyzny regionalnej pod kątem geograficznym, genetycznym oraz semantycznym.

O zróżnicowaniu regionalnym ziem etnicznie polskich w dobie nowopolskiej wiadomo stosunkowo niewiele, można zatem przypuszczać, że uzyskane w pracy wnioski wypełniają dotkliwą (i w sensie naukowym, i w sensie społecznym - z uwagi na społeczną doniosłość problematyki regionalnej) lukę $\mathrm{w}$ dotychczasowym dorobku językoznawstwa polonistycznego.

${ }^{1}$ Mimo że słownik ten został wydany poza dobą nowopolską, uwzględniono go w pracy jako jedno ze źródeł z omawianego okresu. Przemawia za tym fakt, iż zgromadzono w nim jeszcze przedwojenny materiał leksykalny.
Studia onomastyczne i dialektologiczne, pod redakcją Alicji Pihan-Kijas owe j i Ireny Sarnowskiej-Giefing, „Poznańskie Spotkania Językoznawcze” t. 22, Wydawnictwo Poznańskiego Towarzystwa Przyjaciół Nauk, Poznań 2011, ss. 179.

Studia onomastyczne $i$ dialektologiczne z podtytułem Carolo Zierhoffer professori clarissimo ukazały się jako 22. tom czasopisma „Poznańskie Spotkania Językoznawcze”, którego redaktorem naczelnym jest Alicja Pihan-Kijasowa. Studia... dedykowano Profesorowi Karolowi Zierhofferowi na Jego 85. urodziny. Na tom składa się artykuł wstępny autorstwa Ireny Sarnowskiej-Giefing, prezentujący sylwetkę Jubilata (wraz z ciekawymi, nigdy wcześniej niepublikowanymi zdjęciami), oraz 11 artykułów naukowych zgrupowanych w dwóch działach: Onomastyka i Dialektologia.

Zygmunt Zagórs ki, Językoznawstwo polskie na Uniwersytecie im. Adama Mickiewicza w latach 1919-2009 (w zarysie), „Poznańskie Spotkania Językoznawcze" zeszyt specjalny, Wydawnictwo Poznańskiego Towarzystwa Przyjaciół Nauk, Poznań 2011, ss. 145.

Osiągnięcia językoznawstwa polonistycznego na przestrzeni 90 lat istnienia Uniwersytetu im. Adama Mickiewicza autor przedstawia w siedmiu działach: Historia języka polskiego, Onomastyka, Współczesny język ogólnopolski, Odmiany formalno-funkcjonalne i style języka ogólnopolskiego, Dialektologia, $Z$ dziejów językoznawstwa polskiego oraz Dydaktyka. Pracę otwiera informacja o jej autorze, pióra Stanisława Mikołajczaka.

Sporządziła Agnieszka Krygier-Łaczkowska 